\title{
Protective and Therapeutic Effect of Green Tea (Camellia sinesis) against Rat Prostate Cancer
}

\author{
Mohamed, I.A. Heibashy; Amal, M. El-Nahla* and \\ Sherif, Y. A. Saleh** \\ Biological Application Department, Nuclear Research Center, \\ Atomic Energy Authority, Egypt \\ Physiology* and Biochemistry** Departments, \\ Faculty of Veterinary Medicine, Suez Canal University
}

\begin{abstract}
This investigation was conducted to evaluate the protective and therapeutic effect of green tea to ameliorate the deleterious effects of prostate cancer in rats. The obtained data revealed a significant elevation in tumor markers (PSA, TAP and PAP levels) after induction of cancer prostate in rats in comparison with the normal control one. Also, there was a significant decrease in total testosterone, free testosterone and DHEA-S concentrations, but the serum MDA level was increased significantly in rats with cancer prostate as compared with the corresponding levels in control rats. On the other hand, administration of green tea before or/and after induction of prostate cancer in rats led to a considerable improvement in the previous parameters but, their values did not revert to normal level. Any how, the results of the present investigation showed that the green tea when taken before and after induction of cancer prostate gave the prophylactic and therapeutic effects. The underlying mechanisms through which green tea counteracted cancer prostate were discussed.
\end{abstract}

Key words: Green tea, Prostate cancer, Tumor markers, Rats.

\section{INTRODUCTION}

Prostate cancer (PCa) is one of the biggest killers of men and is often referred to as the hidden cancer because it can develop without any obvious symptoms. It has become the second leading cause of related death $^{(\mathbf{1 , 2})}$. It is a malignant tumor which was considered a major cause of morbidity and mortality in men ${ }^{(3)}$. It is therefore necessary to forward efforts to diagnose and manage that disease early through developing novel approaches for its diagnosis, prevention and treatment.
Chemoprevention involving the use of natural agents to prevent or reverse the process of carcinogenesis could be an effective approach to reduce the progression of $\mathrm{PCa}^{(4)}$. Development of effective chemopreventive and agents against $\mathrm{PCa}$ in human, however, requires conclusive evidence of their efficacy in animal models that closely emulate human disease and possess surrogate endpoint biomarkers for rapid evaluation of chemopreventive and/or therapeutic agents ${ }^{(5)}$.

Tea polyphenols have been proposed as potential 


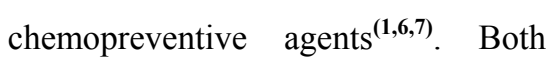
green and black tea and their constituents have been extensively studied both in vitro and in animal models of carcinogenesis ${ }^{(7,8)}$. Green tea is derived from the plant Camellia sinensis, which is widely consumed allover the world ${ }^{(5)}$. It is chemically characterized by the presence of large amount of polyphenolic compounds known as catechins including epicatechin gallate (ECG), epicatechin (EC), epigallocatechin 3-gallate (EGCG), and epigallocatechin $(\mathrm{EGC})^{(9)}$.

The role of tea in cancer prevention is supported by results from a large number of studies in animal models carried out over more than a decade ${ }^{(\mathbf{9}, 10)}$. Using the transgenic adenocarcinoma mouse prostate model of prostate carcinogenesis, it was demonstrated that oral consumption of $0.1 \%$ of green tea polyphenols decreased tumor incidence by $65 \%^{(\mathbf{1}, 6,11)}$.

Based on the standing of animal models of carcinogenesis and the bioavailabilty of the tea polyphenol, the present article was planned to explain the potential relevance of these models to cancer protection in rats.

\section{MATERIALS \& METHODS}

Fifty adult male albino rats (Rattus rattus) at 8 weeks of age were obtained from the Animal House of Nuclear Research Center, Inshas, Egypt. They were maintained in plastic cages at $23^{\circ} \mathrm{C}$, housed in a well ventilated animal house and kept under the same managerial and environmental conditions. The animals were fed to appetite on a standard laboratory animal diet according to the National Research Council $(N R C)^{(\mathbf{1 2})}$. Deionized water was available all time.

Rats were divided randomly into five equal groups (ten for each). Rats of the first group (negative control) were injected subcutaneously with $500 \mu \mathrm{l}$ of physiological saline $(0.9 \%$ $\mathrm{Na} \mathrm{Cl}$ ) daily for 8 weeks. Members of the second group (postive control) received orally $50 \mathrm{mg}$ cyproterone acetate (Sigma Chem. Co., St. Louis, Mo, USA $/ \mathrm{kg}$ body weight daily for 21 consecutive days. Cyproterone acetate inhibits androgen secretion from the testis, thereby causing atrophy of prostatic epithelial cells. Starting on the day after the last injection of cyproterone acetate, rats received s.c. injections of $100 \mathrm{mg}$ testosterone propionate (Sigma Chem. Co., St. Louis, Mo, USA) $/ \mathrm{kg}$ body weight daily for another 21 days. That sequence of antiandrogen treatment followed by androgen treatment synchronizes and stimulates cell proliferation in the prostate and thereby maximizes neoplastic development in response to a single dose of chemical carcinogen ${ }^{(\mathbf{1 3})}$. Twenty four hours after the last dose of testosterone propionate, rats received $50 \quad \mathrm{mg} \quad \mathrm{N}$-methyl-Nnitrosurea (MNU) (Sigma Chem. Co., St. Louis, Mo, USA) dissolved in sterile saline ( $\mathrm{pH} 5.0) / \mathrm{kg}$ body weight as a single i.v injection ${ }^{(\mathbf{1 4})}$. After induction of cancer prostate, blood samples were withdrawn from tail vein of rats and PSA was assayed in order to determine the incidence of prostate cancer. Rats of the third group received green tea as a drinking 
water for 8 weeks before induction of prostate cancer by the same previous method. Green tea solution was prepared freshly every day as follow, $5 \mathrm{~g}$ of commercial green tea (Arab Co. for Pharm. and Medicinal Plants (MEPACO), Inshas, Egypt) were boiled in $100 \mathrm{ml}$ boiling water for five minutes, allowed to stand at room temperature an hour before use. In the fourth group prostate cancer was induced firstly by previous method then green tea was administered in the same dose for 8 weeks. The last group received green tea four weeks before and four weeks after prostate cancer induction. At the end of the experimental period ( 8 weeks), rats were scarified by decapitation and the blood samples were collected from each group of the rats in clean dry test tubes and sera were separated and stored frozen under- $20^{\circ} \mathrm{C}$ until analysis.

Serum total acid phosphatase (TAP) activity was determined kinetically using commercial kits (Bio Merieux Co., Mary-L-Eolilie, Chorbonnieres, Les- Brain, France) ${ }^{(\mathbf{1 5})}$. Prostatic acid phosphatse (PAP) activity was assessed by ELISA using commercial kits (IBLGesellschapt, Hamburg, Co., Germany) $)^{(\mathbf{1 6})}$. Testosterone ${ }^{(\mathbf{1 7})}$, free testosterone $^{(\mathbf{1 8})}$ and dehydroepiandrosteron sulfate $(\text { DHEA-S })^{(\mathbf{1 9})}$, prostatic specific antigen (PSA) ${ }^{(\mathbf{2 0}, 21)}$ levels were estimated by radioimmunoassay (RIA) using solid phase system. The kits were purchased from Diagnostic Product Corporation (DPC) USA. Serum malondialdehyde (MDA) ${ }^{(\mathbf{2 2})}$ was determined by ELISA technique using commercial kit (Cayman Chem. Co., USA).

All data were statistically analyzed using one way analysis of variance (ANOVA) followed by Duncan's multiple range test according to Snedecor and Cochran $^{(\mathbf{2 3 )}}$ using a computer program (Costate).

\section{RESULTS \& DISCUSSION}

The incidence of prostate tumors was reported to increase exponentially with age including benign prostatic hyperplasia, which tends to occur in the transitional zone and adenocarcinoma, which arises mainly in the peripheral zone ${ }^{(23)}$. Cancer is a fermentative disease caused by a compromised robust oxidative mechanism, giving uncontrolled cellular growth ${ }^{(25,26)}$.

In the current study, it is obvious that rats treated with $\mathrm{N}$-methyl-Nnitrosurea in the presence of cyproterone acetate an inhibitor of androgen secretion and testosterone propionate as stimulator of cell proliferation in the prostate, showed a significant $(\mathrm{P}<0.05)$ elevation in the activity of TAP and PAP beside the levels of PSA and MDA in serum as compared to negative control one (Table 1). PSA is a specific tumor marker for prostate carcinoma, thus these results are anticipated and promoted to the occurrence of prostate cancer. Ruddon $^{(27)}$ reported that the level of PSA in serum is liable to detection if there is a tumor in the prostate. Many authors attributed the elevation in the tumor marker level due to the elevation of free radical production, lipid peroxidation, DNA 
damage, mutation in DNA, abnormalities of gene sequence and disturbance in the cytochrome $\mathrm{P} 450^{(\mathbf{1 , 2 , 2 8})}$. TAP and PAP leaks into the serum from the damaged prostate gland and elevation in its activity suggest the presence of metastatic prostatic carcinoma or at least prostatic damage as the level of increased activity depends upon the size of lesion ${ }^{(\mathbf{2 9})}$. These results are in harmony with those obtained by Heibashy and Badie-Bakshwan ${ }^{(\mathbf{3 0})}$.

It has been postulated that carcinogen may increase tissue oxidative stress with accelerated lipid peroxidation which subsequently induces DNA damage ${ }^{(29,31)}$ or synthesis of prostaglandins and leukotrienes that stimulate prostate cancer cell proliferation $^{(\mathbf{3 2})}$, that could explain the elevated MDA level in prostate cancer group of the current study (Table. 1). As, lipolysis of stored fat releases glycerol and fatty acid oxidation of which are increased in cancer patients ${ }^{\mathbf{( 3 3 )}}$. Also, Ruddon ${ }^{(\mathbf{2 7})}$ reported that tumor cells are found to have abnormal activities of antioxidant enzymes and this explain the elevated level of MDA. As well, Heibashy ${ }^{\mathbf{( 2 8 )}}$ found that tumor cells are low in activities of SOD and catalase.

Dehydroepiandrosterone (3 betahydroxy-5-androstene-17 one; DHEA) and its conjugates are abundant circulating steroids that originate largely from the adrenal cortex and to a lesser extent by the testes and ovaries. It is a precursor in the body for synthesis of testosterone, estradiol and a number of other steroid hormones ${ }^{(34)}$. DHEA and DHEA-S have shown protection against tumors by blocking carcinogen-induced cell transformation and depressing the mitogenic effects of carcinogens ${ }^{(35)}$, also they were shown to inhibit prostate cancer induction in rats ${ }^{(36)}$. In the present work, rats with prostate cancer exhibited lower level of DHEA-S corresponding to higher levels of PSA, PAP, TAP and MDA (Table. 1). These results may explain the oxidative stress that, can play a major role in induction of prostate cancer. Moreover, DHEA-S is able to inhibit certain enzymes involved in the formation of free radicals by increment the levels of reduced glutathione $^{(3)}$ and enhancement of the activity of superoxide dismutase, glutathione peroxidase and catalase $^{(34)}$. Also, DHEA-S reduces the lipid peroxidation level by preserving the cellular reduced glutathione $^{(3)}$. Another study found that, DHEA may also be effective in enhancing the function of the immune system, which may play a role in cancer defense $^{(37)}$.

In relation to reproductive performance, the obtained data showed a significant $\quad(\mathrm{P}<0.05)$ reduction in total testosterone and free testosterone in rats with cancer prostate group (positive control) when compared to negative control one. These results may be attributed to either the conversion of testosterone to dihydrotestosterone (DHT) which is an important factor in the development of prostate cancer as it stimulates the growth and proliferation of cancerous prostate cells and therefore is the primary fuel for the growth of prostate cancer ${ }^{(14,38)}$, or may be due to the negative feedback caused by injected testosterone. 
The obtained data in (Table. 1) showed a significant improvement in prostate tumor markers (PSA, TAP and PAP) levels as well as total testosterone, free testosterone, DHEA$\mathrm{S}$ and MDA concentrations, when green tea were either given before cancer induction, after cancer induction and/or when taken before and after cancer induction when compared to rats with cancer prostate but all of these parameters did not return to their normal levels.

Green tea is particularly rich in polyphenols, including catechins, theaflavins and thearubigins, which are thought to contribute to the health benefits of tea. These polyphenols act as antioxidants in vitro by scavenging reactive oxygen and nitrogen species and chelate redox-active transition metal ions. They may also act indirectly as antioxidants through $\boldsymbol{I}$ ) inhibition of the redox-sensitive transcription factors, nuclear factor- $\beta$ and activator protein-1; II) inhibition of "pro-oxidant" enzymes, such as inducible nitric oxide synthase, lipoxygenases, cyclooxygenases and xanthine oxidase; and III) induction of phase II and antioxidant enzymes, such as glutathione S-transferases and superoxide dismutases ${ }^{(39)}$.

The results of the present study showed that administration of green tea may have chemopreventive effect on prostate cancer. The most interesting point obsereved in the current investigation is the improvement in all determined parameters as a result of green tea administration. These results are in parallel with the results of previous study which mentioned that, the polyphenols present in green tea help to prevent the spread of prostate cancer by targeting molecular pathways that shut down the proliferation and spread of tumor cells, as well as inhibiting the growth of tumor nurturing blood vessels ${ }^{(\mathbf{4 0 )} \text {. }}$ These results may be due the role of green tea polyphenols (GTP) in modulating the insulin-like growth factor-1 (IGF-1), by reducing its levels or by increasing the levels of one of the binding proteins for IGF-1. This explanation bears a significance in light of studies that indicated an increase in the levels of IGF-1 which associated with increased risk of several cancers, such as prostate, breast, lung and colon. Moreover, GTP also caused a reduction in the expression of proteins known to be associated with the metastatic spread of cancer cells, as it inhibited the level of urokinase plasminogen activator as well as matrix metalloproteinases 2 and 9, cellular molecules linked to the metastasis. GTP contributed to minimize tumor development by governing the amount of vascular endothelial growth factor (VEGF) in the serum of the prostate cancer mouse model. The reduction of VEGF may result from GTP-induced suppression of IGF-1 levels. VEGF acts to recruit and develop new blood vessels that carry nutrients to developing tumors. By reducing the amount of VEGF, GTP works to minimize nutrients flowing and supporting tumor growth ${ }^{(40)}$.

Furthermore, the protective effect of GTP may be due to its blockage effect on the production of oxygen free radicals derived during carcinogenesis, enhancement of the levels of antioxidants defense 
enzymes system by increasing the activities of some enzymes which convert the oxidized molecules to their reduced form ${ }^{(39)}$. In vivo, some studies have shown that, catechins are hypothesized to help protection against ROS by increasing total plasma antioxidant activity ${ }^{(41,42)}$. So, the decrement in the level of MDA shown in prostate cancer rats after treated with green tea (Table 1), may be attributed to catechins present in the tea which have a direct or indirect antioxidant effect ${ }^{(41,43)}$. Also, GTP exhibit modifying influence on the protein phosphorylation process ${ }^{(44)}$ and following catalytic activities of many enzymes especially the oxidant ones $^{(45)}$.

The tea polyphenols consist of strong metal ion chelators such as iron and copper which are required for generation of reacrive oxygen radicals by means of Benton and Haber Weiss reactions $^{(\mathbf{4 6})}$. Moreover, oral feeding of green tea leaves to rats resulted in enhanced SOD activity in serum and catalase activity in liver and an increased concentration of glutathione in the liver ${ }^{(47)}$. Thus, antioxidants present in green tea could contribute to the preventive effect on cancer ${ }^{(48)}$.

Interaction of tea flavonoid with pro-carcinogens plays a prominent role of the beneficial effects of tea against cancer initiation. Masuda et al. ${ }^{(49)}$ examined the influence of EGCG and ECG on protein kinase activator, EGCG blocks the interaction between proteins and ligands while, both EGCG and ECG inhibit the gap functional intracellular communication caused by tumor promoters. Thus, tea polyphenol can interact with enzymatic defense mechanisms in cells and contribute to cancer prevention at the early stage of carcinogenesis $^{(\mathbf{1 1}, \mathbf{4 9}, \mathbf{5 0}, \mathbf{5 1})}$.

Flavonoids present in tea can also exert a protective effect on cancer promotion. They maintain normal growth by blocking the activation of an oncogene activator protein (AP), maintain cell-cell communication and apoptosis of malfunctioning cells ${ }^{(\mathbf{4 8 , 5 2})}$. Prevention of cancer may be also studied through anti-mutagenic protective properties of green tea. EGCG has reactive oxygen species (ROS) scavenger property and the most potent antimutagenic agent protecting DNA scissions and nonenzymatic interception of superoxide anions. ECG emerges as the most potent enzymatic scavenger amongst the green tea polyphenol $^{(11,53,54)}$.

Although, numerous health benfites have been proposed for the consumption of tea, the effectiveness of tea as a cancer preventive agent in human remains unclear because animal models of carcinogensis may be different from the human situation. Judging from the inhibitory activities of tea polyphenols observed in the present study in animal model, it is likely that there are multiple mechanisms by which tea constituents induce inhibitory effects against prostate cancer either as prophylactic and therapeutic agent. To this end information on the biotransformation, bioavailability and tissue level of theaflavins, EGCG, ECG and other tea constituent should be a vital goal for future mechanistic researches. Further studies are required to determine the best dosage and route by which tea constituents deliver to 
certain organ. More detailed molecular cellular mechanism studies in animals and humans are needed because the results of the previous researches will help to verify the effects of tea in humans by comparison with studies in animals.

Table (1): Chemo protective effects of green tea on prostate cancer in rats

\begin{tabular}{|c|c|c|c|c|c|}
\hline $\begin{array}{c}\text { Treatment } \\
\text { Groups }\end{array}$ & $\begin{array}{c}\text { Group } \\
\text { I }\end{array}$ & Group & $\begin{array}{l}\text { Group } \\
\text { III }\end{array}$ & $\begin{array}{l}\text { Group } \\
\text { IV }\end{array}$ & $\begin{array}{c}\text { Group } \\
\text { V }\end{array}$ \\
\hline $\begin{array}{c}\text { PSA } \\
(\mathrm{ng} / \mathrm{ml})\end{array}$ & $\begin{array}{c}0.152 \pm \\
0.04^{\mathrm{a}}\end{array}$ & $\begin{array}{l}1.752 \pm \\
0.23^{b}\end{array}$ & $\begin{array}{l}1.416 \pm \\
0.19^{\mathrm{c}}\end{array}$ & $\begin{array}{l}1.138 \pm \\
0.24^{\mathrm{d}}\end{array}$ & $\begin{array}{r}0.639 \\
\pm 0.18^{\mathrm{e}}\end{array}$ \\
\hline $\begin{array}{l}\text { TAP activity } \\
(\mathrm{U} / \mathrm{L})\end{array}$ & $\begin{array}{c}1.974 \pm \\
0.09^{\mathrm{a}}\end{array}$ & $\begin{array}{c}3.056 \pm \\
0.17^{\mathrm{b}}\end{array}$ & $\begin{array}{c}2.754 \pm \\
0.19^{\mathrm{c}}\end{array}$ & $\begin{array}{c}2.458 \pm \\
0.19^{d}\end{array}$ & $\begin{array}{l}2.249 \\
\pm 0.15^{\mathrm{e}}\end{array}$ \\
\hline $\begin{array}{c}\text { PAP activity } \\
(\mathrm{U} / \mathrm{L})\end{array}$ & $\begin{array}{c}0.642 \pm \\
0.05^{\mathrm{a}}\end{array}$ & $\begin{aligned} & 1.787 \\
+ & 0.023 b\end{aligned}$ & $\begin{array}{c}1.493 \pm \\
0.22^{\mathrm{c}}\end{array}$ & $\begin{array}{l}1.107 \pm \\
0.16^{\mathrm{d}}\end{array}$ & $\begin{array}{c}0.899 \\
\pm 0.09\end{array}$ \\
\hline $\begin{array}{l}\text { Testosterone } \\
(\mathrm{ng} / \mathrm{ml})\end{array}$ & $\begin{array}{c}1.827 \pm \\
0.08^{\mathrm{a}}\end{array}$ & $\begin{array}{l}0.659 \pm \\
0.07^{\mathrm{b}}\end{array}$ & $\begin{array}{c}0.881 \pm \\
0.11^{\mathrm{c}}\end{array}$ & $\begin{array}{l}1.128 \pm \\
0.08^{d}\end{array}$ & $\begin{array}{l}1.367 \pm \\
0.09\end{array}$ \\
\hline $\begin{array}{c}\text { Free } \\
\text { Testosterone } \\
(\mathrm{Pg} / \mathrm{ml})\end{array}$ & $\begin{array}{c}0.693 \pm \\
0.01^{\mathrm{a}}\end{array}$ & $\begin{array}{c}0.181 \pm \\
0.02^{b}\end{array}$ & $\begin{array}{c}0.237 \pm \\
0.03^{\mathrm{c}}\end{array}$ & $\begin{array}{l}0.416 \pm \\
0.05^{\mathrm{d}}\end{array}$ & $\begin{array}{l}0.589 \\
\pm 0.02^{\mathrm{e}}\end{array}$ \\
\hline $\begin{array}{c}\text { DHEA-S } \\
(\mu \mathrm{g} / \mathrm{dl})\end{array}$ & $\begin{array}{r}260.17 \\
\pm 1.94^{\mathrm{a}}\end{array}$ & $\begin{array}{r}127.89 \\
\pm 1.46^{\mathrm{b}}\end{array}$ & $\begin{array}{l}151.46 \\
\pm 1.73\end{array}$ & $\begin{array}{r}192.36 \\
\pm 1.62 \mathrm{~d}\end{array}$ & $\begin{array}{l}227.13 \\
\pm 1.76^{\mathrm{e}}\end{array}$ \\
\hline $\begin{array}{l}\mathrm{MDA} \\
(\mathrm{Um} / \mathrm{dl})\end{array}$ & $\begin{array}{c}0.132 \pm \\
0.02^{\mathrm{a}}\end{array}$ & $\begin{array}{l}0.319 \pm \\
0.09^{b}\end{array}$ & $\begin{array}{c}0.271 \pm \\
0.09^{\mathrm{c}}\end{array}$ & $\begin{array}{c}0.218 \pm \\
0.08^{\mathrm{d}}\end{array}$ & $\begin{array}{c}0.194 \\
\pm 0.06^{\mathrm{e}}\end{array}$ \\
\hline
\end{tabular}

$a, b, c, d, e$ means in the same row with no common superscript are significantly different at $(P<0.05)$.

\section{REFERENCES}

1. Zhou, J.R.; Yu, L.; Zhang, Y. and Blackburn, G.L. (2003): "Soy phytochemicals and tea bioactive components synergistically inhibit androgensensitive human prostate tumor in mice". J. Nutr., 133:516-521.

2. Weir, H.K.; Thun, M.J.; Hankey, B.F.; Ries, L.A.; Howe,
H.L.; Wingo, P.A.; Jemal, A.; Ward, E.; Anderson, R.N. and Edwards, B.K. (2003): “Annual report to the nation on the status of cancer, 1975-2000, featuring the uses of surveillance data for cancer prevention and control". J. Nat. Cancer Inst., 95:1276-99.

3. Rao, K.V.N.; Johnson, W.D.; Bosland, M.C.; Lubet, R.A.; Steele,V.E.; Kelloff, G.J. and 
McCormick, D.L. (1999): "Chemoprevention of rat prostate carcinogensis by early and delayed administration of dehydroepiandrosterone". Cancer Res., 59: 3084.

4. Mukhtar, H. \& Ahmad, N. (1999):

"Cancer chemoprevention: future holds in multiple agents: contemporary issues in toxicology". Toxicol. Appl. Pharmacol., 158:207-210.

5. Adham,V.M.; Nihal, A. and Hasan, M. (2003): "Molecular targets for green tea in prostate cancer prevention". J. Nutr., 133:2417S-2424S.

6. Dashwood, R. H. (2007): "Supplement: International Research Conference on Food, Nutrition, and Cancer Frontiers in Polyphenols and Cancer Prevention". J. Nutr., 137:267S269S.

7. Crespy, V. and William Son, G. (2004): "A review of the health effects of green tea catechins in in vivo animal models". J. Nutr., 134:3431S-3440S.

8. Lamb, D.J. and Zang, L. (2005): "Challenges in prostate cancer research: animal modles for nutrition studies of chemoprevention and disease progression". J.Nutr., 135:3009530155.

9. Chung, S.; Yang, J. Y.; Chung, G. Y.; Saranjit, K. C. and MaoJung, L. (2000): "Tea and tea polyphenols in cancer prevention". J. Nutr., 130: 472S$478 \mathrm{~S}$.

10. Chung, F.L; Schwartz, J.; Herzog, C.R. and Yang, Y.M. (2003): "Tea and cancer prevention: studies in animal and humans". J.Nutr., 133:3268s3274s.

11. Gupta, S.; Hastak, K.; Ahmad, N.; Lewin, J. S. \& Mukhtar, H. (2001): "Inhibition of prostate carcinogenesis in TRAMP mice by oral infusion of green tea polyphenols". Proc. Nat. Acad. Sci., 98:10350-10355.

12. NRC National Research Council; (1977): "Nutrient requirement of domestic animals, nutrient requirements of rat." National Academy of Science, Washington, DC, U.S.A.

13. Bosland, M.C. and Prinsen, M.K. (1990): "Induction of dorsolateral prostate adenocarcinoma and other accessory sex gland lesions in male wistar rats" Cancer Res., 50:691.

14. Bosland, M.C. (1996): "Hormonal factors in carcinogenesis of the prostate and testis in humans and animal models" In: J. Huff, J. Boyd and J.C. Barrett ed. Cellular and Molecular Mechanisms of Hormonal Carcinogenesis; Environmental Influences, New York (NY): Wiley - Liss; Pp., 309.

15. Hillman, G. (1971): "Fortulaujed photometrische messung der sauren phosphatase aktivtat". Z. Klin. Chem. Klin. Biochem., 9:273.

16. Valcour, A. A.; Bowers, G. N. J. and Mc Comb, R. B. C. (1989): "Evaluation of a method for prostatic acid phosphatase with use of self indicating substrate 2,6. dichloro-4- 
nitrophenyl phosphate". Clin. Chem., 35:939.

17. Jaffe, B. M. and Behrman, N. R. (1974): "The role of testosterone measurements in the investigation of androgen disorders ". Ann. Clin. Biochem., 13:113. In "Handbook of radioimmunoassay" ed by Abraham, G. E.

18. Mc Cann, D. and Kirkish, L. (1985): "Evaluation of free testosterone in serum" J. Clin. Immunoassay. 8:334.

19. De Peretti, E. and Forest, $M$. (1978): "Pattern of plasma dehydroepiandrosterone sulfate level in humans from birth to adulthood: Evidence for testicular production". J. Clin. Endocrinology Metab., 47:572.

20. Wang, M.C.; Lang, P. H. and Chan, D. W. (1979): "Purification of a human prostate specific antigen". Invest. Urol., 17:159.

21. Kuriyama, M.; Nadj, M.; Lee, P. J. and Watt, W. K. (1982): "Prostatic acid phosphatase and prostate specific antigen in prostate cancer". Cancer Res., 42: 3957

22. Hogberg, J.; Larson, R. E.; Kristoferson, A. and Orrenius, S. (1974): "NADPH-dependent reductase solubilised from microsomes by peroxidation and its activity". Biochem. Biophys. Res. Commun., 65:836-842.

23. Snedecor, G. W. and Cochran, W. C. (1982) "Statistical method" 7th Ed. The Low. Univ. press, Ames Lowa, U.S.A.

24. Jones, G.W. (1993): "Prostate cancer: magnitude of the problem. Am. College of surgeons database and epidemiologic study". Cancer (Phila) 71:887.

25. Thomas, J.H. and Gillham, B. (2000): "Carcinogenesis". In:Wills Biochemical Basis of Medicine. 2nd ed. London Boston Singapore Sydney Toronto Wellington. Pp. 477.

26. Daniel, W.C.; Mc-Lean, A. and Thomas, G. (2002): "Tumor Markers" 5th ed. Lang Medical Publication Less, Atlas, California, U.S.A.

27. Ruddon, R.W. (1995): "Cancer Biology". 3rd ed. Oxford University Press.

28. Heibashy, M.I.A. (2005): "Modulatory effects of vitamin E, selenium or their mixture on the $\mathrm{N}$-nitrosodiethylamine (NED) induced oxidative stress in male albino rats". J. Egypt. Ger. Soc. Zool., 47(A):17.

29. Heibashy, M.I.A. (2000): "Alteration in hematological, renal and testicular functions of rats after lead exposure and the beneficial effect of administration of taurine as antioxidant agent". J. Egypt. Ger. Soc. Zool., 14: 11.

30. Heibashy, M.I. and BadieBakshwan, S. (1999): "The harmful effects of adriamycin on testicular function of rats and the therapeutic or protective role of taurine". Egyptian J. Med. Sci., 20(2):613.

31. Fleshner, N.E. and Kucuk, O. (2001): "Epidemiological evidence and prop mechanisms urology". Urolo., 57:90.

32. Liu, X.H.; Yao, S.; Kirschenbaum, A. and Levine, 
A.C. (1998): "Progression of prostatic intraepithelial neoplasia and other prostatic lesions as risk factors". Cancer Res., 58:4245.

33. Hyltander, A.; Drott, C.; Körner, U.; Sandström, R. and Lundholm, K. (1991): "Prospective origins of prostate carcinoma: prostatic intraepithelial neoplasia and atypical adenomatous hyperplasia". Eur. J. Cance., 27:349-354.

34. Gaby, A.R. (1996): "Cancer prevention with dehydrepiandrosterone". Alt. Med. Rev., 1 (2):60.

35. Gordon, G.B.; Shantz, L.M. and Talalay, P. (1987): "Modulation of growth, differentiation and carcinogenesis by dehydrepiandrosterone". Adv. Enzyme Regul., 26:355.

36. Mc Cormick, D.L. and Rao, K.V. (1999): "Age and racial distribution of prostatic intraepithelial neoplasis". Eur. Urol., 35:464.

37. Zhang, $Z$. and Watson, $R$. (1999): "DHEA in immune modulation and aging", In Health Promotion and Aging, R. Watson, ed. Harwood Acad. Pub., 113.

38. Qing, J.; Lilly, C.; Frank, Z.; Stanczyk, M.; Andy, S. and Andrew, S. (2007): "Impaired dihydrotestosterone catabolism in human prostate cancer: critical role of AKR1C2 as a pre-receptor regulator of androgen receptor signaling”. Cancer Res., 67:13611369.

39. Balz, F. and Jane, V. H. (2003): "Antioxidant activity of tea polyphenols in vivo: Evidence from Animal Studies". J. Nutr., 133:3275S-3284S.

40. Mukhtar, H.; Vaqar, M. A.; Imtiaz, A. S. and Nihal, A. (2004): "Green tea polyphenols thwart prostate cancer development at multiple levels". Cancer Rese., 54:1240-1247.

41. Yokozawa, T.; Nakagawa, T. \& Kitani, K. (2002): "Antioxidative activity of green tea polyphenol in cholesterol-fed rats". J. Agric. Food Chem., 50: 3549-3552.

42. Negishi, H.; Xu, J. W.; Ikeda, K.; Njelekela, M.; Nara, Y. \& Yamori, Y. (2004): "Black and green tea polyphenols attenuate blood pressure increases in stroke-prone spontaneously hypertensive rats". J. Nutr., 134:38-42.

43. Yokozawa, T.; Nakagawa, T.; Lee, K. I.; Cho, E. J.; Terasawa, K. \& Takeuchi, S. (1999): "Effects of green tea tannin on cisplatin-induced nephropathy in LLC-PK1 cells and rats". J. Pharm. Pharmacol., 51:1325-1331.

44. Middleton, E. (1998): "Green tea and skin anticarcinogenic effects". Adv. Exp. Med. Biol., 49:438.

45. De-Groat, $H$. and Rauen, U. (1998): "Tea consumption and cancer fundam". Clin. Pharmacol., 12:249.

46. Stief, T. W. (2003): "The physiology and pharmacology of singlet oxygen". Med. Hypoth., 60:567-72.

47. Lin, Y. L.; Tsai, S. H.; LinShiau, S. Y.; Ho, C. T. \& Lin, J. K. (1999): "Theaflavin-3, 3'digallate from black tea blocks 
the nitric oxide synthase by down-regulating the activation of NF-kappaB in macrophages". Eur. J. Pharmacol., 367:379-388.

48. Yang, C. S.; Maliakal, P. \& Meng, X. (2002): "Inhibition of carcinogenesis by tea". Annu. Rev. Pharmacol. Toxicol., 42:2554.

49. Masuda, M.; Suzui, M. \& Weinstein, I. B. (2001): "Effects of epigallocatechin-3-gallate on growth, epidermal growth factor receptor signaling pathways, gene expression, and chemosensitivity in human head and neck squamous cell carcinoma cell lines". Clin. Cancer Res., 7:42204229.

50. Liang, Y. C.; Lin-shiau, S. Y.; Chen, C. F. \& Lin, J. K. (1997): "Suppression of extracellular signals and cell proliferation through EGF receptor binding by () -epigallocatechin gallate in human A431 epidermoid carcinoma cells". J. Cell. Biochem., 67:55-65.
51. Nam, S.; Smith, D. M. \& Dou, Q. P. (2001): "Ester bondcontaining tea polyphenols potently inhibit proteasome activity in vitro and in vivo". J. Biol. Chem., 276:13322-13330.

52. Joshua, D. L. and Chung, S. Y. (2003): "Mechanisms of cancer prevention by tea constituents". J. Nutr., 133:3262S-3267S.

53. Berger, S. J.; Gupta, S.; Belfi, C. A.; Gosky, D. M. \& Mukhtar, H. (2001): "Green tea constituent ( )-epigallocatechin3-gallate inhibits topoisomerase $\mathrm{i}$ activity in human colon carcinoma cells". Biochem. Biophys. Res. Commun., 288:101-105.

54. Jung, Y. D.; Kim, M. S.; Shin, B. A.; Chay, K. O.; Ahn, B. W.; Liu, W.; Bucana, C. D.; Gallick, G. E. \& Ellis, L. M. (2001): "EGCG, a major component of green tea, inhibits tumour growth by inhibiting VEGF induction in human colon carcinoma cells". Br. J. Cance., 84:844-850. 


\section{الاور الوقائى والعلاجى للشاى الاخضر ضد مرض سرطان البروستاتحا فى الجرذان الافنير فان

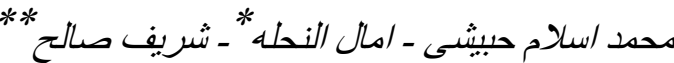

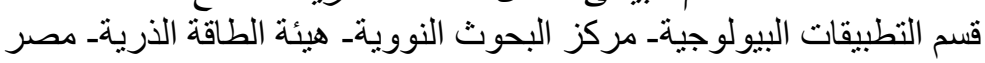
قسمي *|الفسيولوجيا ** الكيمياء الحيوية ـ كلية الطب البيطرى النئ- جامعة قناة السويس

اجريت هذه الدر اسة لإلقاء الضوء على الدور الوقائى و العلاجى للفينو لات المتعدده بالثاى الاخضر ضد مرض سرطان البروستاتا في الجرذان.

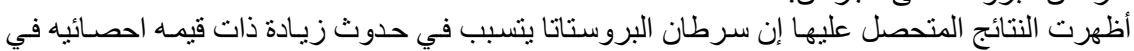

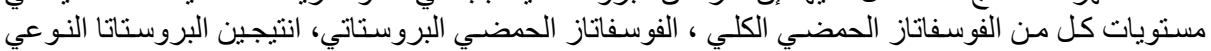

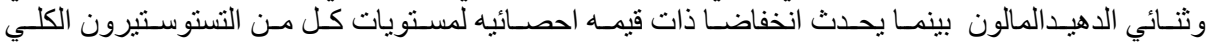

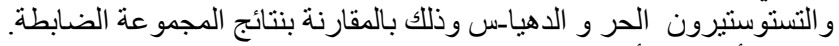

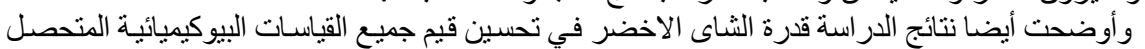

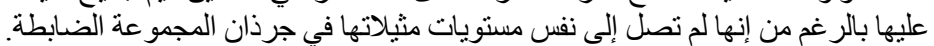

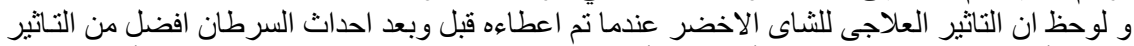

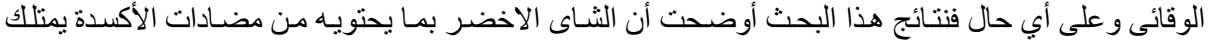

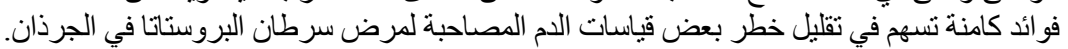

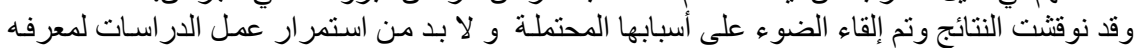

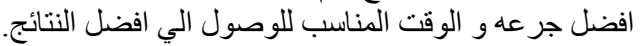

